\title{
THE EFFECT OF HYPERURICEMIA HERBS DRINK ON THE QUALITY OF LIFE
}

\author{
Agus Triyono, Widhi Astana, Fajar Novianto, Zuraida Zulkarnain, \\ Ulfa Fitriani, Ulfatun Nissa, Danang Ardianto \\ Research Center and Development of Traditional Medicinal and Medicinal Plants, \\ Tawangmangu, Karanganyar, Central Java, Indonesia
}

\begin{abstract}
Background: The prevalence of hyperuricemia increased rapidly in recent years and has closely interdependent relationship with other metabolic disorders. Conventional medication drugs are usually associated with many side effects. About 75 to $80 \%$ of the world population use herbal medicines, mainly in developing countries, for primary health care because of their better acceptability with human body and lesser side effects. This study aimed to examine the effect of hyperuricemia herbs drink on the quality of life.

Subjects and Method: A quasi experiment with no control group was carried out at Hortus Medicus clinic, Tawangmangu, Central Java. A sample of 30 hyperuricemia patients (blood uric acid 7-10 mg/dl) was selected for this study. The study subjects consume hyperuricemia herbs drink for 28 days. The dependent variable was quality of life. The independent variables were hyperuricemia herbs drink consumption. Data on quality of life were measured by Short Form36 (SF-36). Mean difference of quality of life score before and after intervention were analyzed by independent $t$ test.

Results: Quality of life score after consuming hypercuremia herbs drink for 28 days (Mean= 80.37; $\mathrm{SD}=11.89$ ) was higher than before (Mean= 76.20; $\mathrm{SD}=15.08)$, and it was statistically significant $(\mathrm{p}=0.001)$. There was no difference of quality of life score (physical function, physical role, mental health social function, and emotional role dimensions) before and after therapy. Conclusion: Hyperuricemia herbs drink for 28 days is effective to improve quality of life.
\end{abstract}

Keywords: hyperurisemia herbs drink, traditional medicine, quality of life

\section{Correspondence:}

Agus Triyono. Research Center and Development of Traditional Medicinal and Medicinal Plants, Tawangmangu, Central Java, Indonesia. Jl. Lawu 11 Tawangmangu, Karanganyar, Central Java, Indonesia. Email: agustriyono_21@yahoo.com. Mobile: o81329038465 